67th scientific conference of professors, teachers, researchers, graduate students and students of the University, 116 - 117 [in Ukrainian].

7. Hafiiak A.M. (2013) Osoblyvosti rozvytku rynku informaciji ta industriji informacijnykh tekhnologhij v umovakh jedynogho informacijnogho prostoru [Features of the development of the information market and the information technology industry in a single information space]. Visnyk nacionaljnogho universytetu "Ljvivsjka politekhnika". Serija: Komp'juterni nauky ta informacijni tekhnologhiji - Bulletin of Lviv Polytechnic National University. Series: Computer Science and Information Technology, 771, 24 - 28 [in Ukrainian].

8. Borodina O.O., Hafiiak A.M., Prosvyetov S.D \& Bilobrov O.R. (2019) Web tekhnolohii v suchasnykh umovakh [Evolution of Web technologies in modern conditions]. Proceedings from MODS '19: VI Mizhnarodna naukovo-praktychna konferentsiia "Matematychne ta imitatsiine modeliuvannia system" - The Nineteenth International Scientific and Practical Conference "Mathematical and simulation modeling of systems" (pp. 256-258). Chernivtsi: TOV "DD "Nauka" [in Ukrainian].

Одержано статтю: 22.09.2019

Прийнято до друку: 19.10.2019

УДК $373.2: 330$

DOI:10.15330/esu.1.127-133
Олександра Кузенко,

кандидат педагогічних наук, доцент,

ДВНЗ “Івано-Франківський національний

медичний університет"

(м. Івано-Франківськ, Україна)

Olexandra Kuzenko,

Candidate of pedagogical sciences $(\mathrm{PhD})$,

Associate Professor, Ivano-Frankivsk National Medical

University (Ivano-Frankivsk, Ukraine)

oleksandrakuz@ukr.net

Катерина Лисенко-Гелемб’юк, кандидат психологічних наук, доцент, ДВНЗ “Прикарпатський національний університет імені Василя Стефаника" (м.Івано-Франківськ, Україна)

Kateryna Lysenko-Gelembiuk, Candidate of psychological sciences (PhD), Associate Professor, Vasyl Stefanyk Precarpathian national university (Ivano-Frankivsk, Ukraine) lysenko.katria@gmail.com

\title{
ФОРМУВАННЯ СОЦІАЛЬНОЇ КОМПЕТЕНТНОСТІ ОСОБИСТОСТІ В ПЕРІОД дОШКІЛЬНОГО ДИТИНСТВА
}

\section{FORMING OF SOCIAL COMPETENCE OF THE INDIVIDUAL DURING THE PRESCHOOL CHILDHOOD}

Оновлення змісту доикільної освіти в умовах демократизачії та духовного відроджения українського суспільства актуалізус необхідність забезпечення сприятливих умов для сочіального розвитку та самовдосконалення особистості, починаючи з дочкільного віку. Результати аналізу психолого-педагогічних досліджень дозволяють визначити напрями сочіалізачії дитини дочкільного віку провідне місче, серед яких належить: 1) забезпеченню адаптачії дитини до сочіального середовица, введення дитини в світ людських взасмин, формувания у дітей відкритості до суспільства; 2) сприянню динаміці і розвитку самоусвідомлення, що дозволить дитині змінювати уявлення про себе і ставлення до себе у прочесі життсоіяльності, формувания готовності до сприймання сочіальної інформачії, 
вихования навичок сочіальної поведінки; 3) формуванно в дитини життсвої позичії, допомога у самореалізачії в суспільстві. Передусім це стосується виховання усвідомленого ставлення до себе як вільної самостійної особистості та до свойх обов'язків, ицо визначається зв'язками з іниими людьми, бажання пізнавати людей, робити добрі вчинки.

Ключові слова: сочіальна компетентність, доикільне дитинство, сочіалізачія.

Updating the content of preschool education in the conditions of democratization and spiritual revival of Ukrainian society actualizes the need to provide favorable conditions for social development and self-improvement of the individual, from preschool age. Socialization of the modern preschooler takes place in the conditions of dynamic social transformations, as a result of which the children have learned the social experience, which positively influences their social competences and the success of social interaction in the following age periods. Therefore, an important scientific problem in modern science has been the study of psychological and pedagogical factors that can ensure the development of a harmonious personality and the development of social competence of the individual during the preschool childhood.

The results of the analysis of psychological and pedagogical researches allow to determine the directions of socialization of a child of preschool age a leading place, among which are: 1) ensuring the adaptation of the child to the social environment, the introduction of the child into the world of human relationships, the forming of openness to society in children; 2) to promote the dynamics and development of self-awareness, which will allow the child to change the self-image and attitude to himself in the process of life, forming a readiness for the perception of social information, education of social behavior skills; 3) forming of life position in the child, assistance in self-realization in society. First and foremost, it concerns the cultivation of a conscious attitude to oneself as a free self and to one's duties, which is determined by relationships with others, the desire to know people, to do good deeds.

Key words: social competence, preschool childhood, socialization.

Постановка проблеми. Соціалізація особистості у дошкільному дитинстві $\epsilon$ важливою соціально-педагогічною проблемою, предметом численних наукових досліджень як у зарубіжній, так і вітчизняній науці. Від ії вирішення безпосередньо залежить усвідомлення дошкільників себе як невід'ємної частини суспільства, формування в них уміння орієнтуватися у доступному суспільному довкіллі, виявляти своє ставлення до соціальної взаємодії відповідно до культурних традицій суспільства. Закономірно, що пріоритетним напрямом педагогічного супроводу розвитку особистості в період дошкільного дитинства в освітній теорії та практиці визначено формування їх здатності встановлювати контакти 3 людьми і діяти в різноманітних комунікативних ситуаціях та реалізовувати способи поведінки.

Аналіз попередніх досліджень. Важливе значення в науковому обгрунтуванні сутності соціалізації дітей дошкільного віку належить працям: В. Бочарової, Т. Василькової, Ю. Василькової, М. Галагузової, Ю. Гапон, Н. Голованової, Н. Заверико, А. Капської, Л. Коваль, Н. Лавриченко, С. Литвиненко, А. Мудрик, С. Савченко, С. Харченко.У результаті досліджень соціалізація трактується як: 1) процес розвитку людини у взаємодії з навколишнім світом (А. Мудрик); 2) мета і вид діяльності педагогічного суб'єкта, тобто як особлива педагогічна дія (Н. Лавриченко); 3) цілісний соціально-педагогічний феномен, що має специфічні педагогічні ознаки: мету, зміст, форми й технології реалізації, кінцевий результат - рівень соціалізованості особистості (С. Савченко).

У дослідженнях В. Анненко, С. Архипової, Т. Афанасьєвої, А. Баркан соціальна компетентність трактується в процесуальному аспекті, характеризуючи iіi 
сутність через діяльність і має виражену діалектичну спрямованість, яка складається 3 компонентів досвіду й забезпечує готовність до діяльності.

Моделюючи вимоги до системи національного виховання, науковці Л.Артемова, А. Богуш, В. Кузь, Н Лисенко, Г. Лозко, Р. Пріма, Н. Рогальська, Ю. Руденко, М. Стельмахович та ін. визначають структурні компоненти цієї системи та засоби їі реалізації, завдяки яким дитина має рівні права і можливості з дорослими на соціальний, психічний, культурний розвиток як особистість та індивід.

Результати досліджень М. Гончаровою-Горянської, О. Кононко, В. Кузьменко, Р.Пацлафом, Т.Поніманської, засвідчують, що особливості розвитку дитини старшого дошкільного віку зумовлюють пріоритетність сфери соціальної компетентності стосовно власного "Я".

Мета статті. Визначити основні напрями психолого-педагогічних досліджень у проблеми формування соціальної компетентності особистості в період дошкільного дитинства.

Виклад основного матеріалу дослідження. Видатний український педагоггуманіст В. Сухомлинський, торкаючись проблеми соціального становлення особистості дитини, влучно зауважив, що “у людині їі людські риси формуються лише тому, шо з першого подиху свого життя вона - істота суспільна. Суспільна сутність людини виявляється в її стосунках, взаєминах з іншими людьми. Пізнаючи світ і себе як частину світу, вступаючи у стосунки з людьми, які задовольняють іiі матеріальні та духовні потреби, дитина залучається до суспільства, стає його членом". За словами В. Сухомлинського, найтонші, найчутливіші корінці правильної соціалізації знаходяться у почуттях і переживаннях, "вони - ніби малесенький магніт, закладений у дитячій істоті, який притягує іiі до інших людей, робить іiі чутливішою, сприйнятливішою до слів, навчань, ідей, настанов" [8, с. 451].

У 80-90-ті pp. XX ст. інтерес до соціалізації як до педагогічного феномену суттєво зростає. У центрі досліджень представників практично всіх суспільствознавчих дисциплін стало визначення структури, функцій, механізмів соціалізації особистості. У зв'язку з процесами демократизації та державотворення в Україні наприкінщі 90-х рр. відбувається становлення нової парадигми виховання, засадами якої $€$ формування загальнолюдських і національних цінностей та ідеалів. На цьому етапі розвитку педагогічної науки увага науковців особливо акцентується на формуванні національної ідентичності особистості, наслідком якої стає іiі національна самоідентифікація.

Психолого-педагогічні аспекти соціалізації особистості стали предметом активних теоретичних та експериментальних досліджень вітчизняних і зарубіжних учених, які одностайні у своїх висновках, що цей процес бере початок на етапі дошкільного дитинства. Дошкільний вік розглядається вченими в якості сензитивного періоду для формування особистості дитини, набуття нею першого соціального досвіду, розвитку емоцій, почуттів, що $є$ підгрунтям їі соціального становлення. 3 огляду на це в усіх розвинених країнах існує дошкільна освіта як перша ланка освітньої системи, що виконує певні соціальні функції, має власні організаційні форми й належні умови для навчання й виховання дітей дошкільного віку та їх соціалізації [1].

Наукове дослідження, здійснене Н.Ф. Головановою, дозволяє визначити основні підходи до педагогічної характеристики поняття “соціалізація”, серед яких:

- соціологічний (Л.Левшин, Х.Лійметс, Т.Мальковська, В.Момов), коли соціалізація тлумачиться в якості передачі досягнень культури від покоління до 
покоління, як загальний механізм соціального успадкування, що охоплює, як стихійні, так і організовані впливи середовища;

- факторно-інституціональний (В.Гінецинський, І.Кон, А.Мудрик), де соціалізація розглядається як сукупність дії факторів, інститутів і агентів соціалізації;

- інтеракціональний підхід (Т.Коннікова, А.Куракін, А.Мудрик, Л.Новікова), що відображає соціалізацію в контексті спілкування, міжособистісної взаємодії;

- інтеріорізаціональний підхід (Б.Бітінас, Л.Буєва, І.Кон, В.Крутецький), у межах якого соціалізація розуміється як процес освосння особистістю норм, цінностей, установок, вироблених суспільством, що приводить до становлення системи внутрішніх регуляторів;

- інтраіндивідуальний підхід, де соціалізація не вичерпується пристосуванням особистості до соціального середовища, а $є$ творчою самореалізацією особистості, удосконаленням себе (І.Кон, А.Кочетов, Т.Мальковська, Л.Рувінський, В.Шепель) [3, с. 193].

Важливо відзначити, що в контексті впровадження в освіту України компетентнісного підходу в дослідженнях теорії організації навчально-виховного процесу активно опрацьовується проблема формування соціальної компетентності. Акцентується на тому, що компетентність - це не лише поінформованість із проблем соціальної взаємодії, а й відповідна поведінка, яка грунтується на знаннях i чуттєвому досвіді.

У Базовому компоненті визначено родинно-побутову та соціально-комунікативну соціальні компетенції дітей дошкільного віку. Родинно-побутова компетенція - це обізнаність вихованців із нормами та правилами сімейного (родинного) співжиття, здатність їх дотримуватися; вміння підтримувати доброзичливі, дружні, довірчі стосунки з усіма членами родини, проявляти турботу i любов до них. Водночас, соціально-комунікативна компетенція включає обізнаність дошкільника 3 різними соціальними ролями людей (знайомі, незнайомі, свої, чужі, діти, дорослі, жінки, чоловіки, дівчатка, хлопчики, молоді, літні тощо); 3 елементарними соціальними та морально-етичними нормами міжособистісних взаємин; уміння дотримуватися їх під час спілкування. У цьому випадко важливою $є$ здатність дитини взаємодіяти з людьми, які ії оточують: узгоджувати свої інтереси, поведінку 3 іншими; усвідомлювати своє місце в соціумі; позитивно сприймати себе; вміння співпереживати, співчувати, допомагати іншим, обирати відповідні способи спілкування відповідно до конкретних життєвих ситуацій [2].

Поняття соціальної компетентності у вітчизняній психологічній науці вперше було вжито О. Вєтошкіним і 3. Гончаровим. Воно було також використане М. Докторович, А. Кукліним як "розуміння цільового призначення соціальних інститутів, норми стосунків й уміння особисто здійснювати соціальні технології. Соціальна компетентність розглядається вченими як адаптаційне явище, в якому функціонування адаптаційного механізму забезпечує соціально-психологічна підготовленість особистості.

Аналізуючи сутність поняття “соціальна компетентність" М.Докторович, акцентує на тому, що слово “соціальний” походить від лат. Socialis - товариський, суспільний, той, що належить суспільству, пов'язаний 3 життям та стосунками людей у суспільстві. Відповідно вчена робить узагальнення, що категорія "соціальна компетентність" інтергує поняття “соціальний” та “компетентність", і виходячи 3 визначень поданих у різних словникових виданнях, виводить трактування соціальної компетентності як: 1) володіння соціальними повноваженнями або певним рівнем 
соціальної компетенції; 2) наявність соціального авторитету, соціальної ваги тощо; 3) володіння соціальними знаннями, які дозволяють існувати та діяти у соціумі [4].

Дослідження, проведені М. Докторович, дозволили їй виокремити основні етапи формування соціальної компетентності: соціальна адаптація, соціальна ідентифікація, індивідуалізація та персоніфікація. Для етапу соціальної адаптації характерне пристосування особистості до мінливих соціокультурних умов. Соціальна адаптація має дві форми, перша 3 яких - активна, відображає прагнення особистості до взаємодії з соціальним середовищем, а друга - пасивна, коли вона не намагається впливати на соціум.

Етап соціальної ідентифікації відображає включеність індивіда в суспільну комунікацію, метою якої є усвідомлення своєї приналежності до певної соціальної групи, його соціальну спрямованість та отримання свого соціального статусу. На етапі індивідуалізації відбувається формування таких якостей та рис особистості, що дозволяють їй бути по-справжньому унікальною, цікавою та корисною для інших. Етап персоніфікації передбачає високий рівень самовизначення та самоствердження особистості, усвідомлення себе суб'єктом соціальної дійсності; соціальну активність як поведінку соціальних суб'єктів, яка спрямована на відтворення та перетворення умов їх життєдіяльності. "Зрозуміло, - стверджує М. Докторович, - що етап персоніфікації відіграє дуже важливу роль у формуванні соціальної компетентності особистості, оскільки пов'язаний $з$ іiі власною діяльністю, спрямованою на соціальний розвиток та становлення.

Результати досліджень М. Докторович доводять, що “соціальна компетентність вимагає від особистості наявності протирічних вмінь та якостей. Вона передбачає як вміння будувати партнерські стосунки, здатність до кооперації, так і достатній рівень конформності, який дозволяє не виходити за рамки соціальних норм; як принциповості, вміння відстояти власну думку, протистояти негативним впливам середовища, так і толерантності, вміння пристосовуватися та ефективно діяти в мінливих соціокультурних умовах. Характеризується наявністю в особистості як досить високого рівня оптимізму, що надає віру в успіх в досягненні мети, так і достатнього рівня песимізму, який надає змогу надолужити прогалини у знаннях та вміннях, що гальмують справу. Соціальна компетентність розуміє під собою як збереження власного пропріуму, так i вміння рахуватися 3 правами та бажаннями інших людей, з недоторканістю їх гідності” [4].

Соціальна компетентність розглядається дослідниками в якості однієї 3 ключових категорій виховної системи, яка пов'язана 3 особливостями розвитку відповідних поведінкових настанов, ціннісних орієнтацій, норм і зразків взаємодії людини 3 навколишнім світом. Соціальна компетентність як один із показників особистісної зрілості потребує розвитку ще в дошкільному віці [5].

Поняття "соціальна компетентність" у дослідженнях С. Архипової, М. Докторович, О. Кононко розглядається як цілісна динамічна структура, складне, багатокомпонентне, багаторівневе, поліфункціональне утворення, яке має значну кількість дефініцій описового характеру, що різняться за обсягом, складом та структурою.

На думку Н. Беккер, соціальна компетентність як інтегроване утворення, що включає в себе систему взаємообумовлених і взаємодоповнюючих компонентів когнітивної, емоційної й поведінкової сфери. саме цуі особистісні сфери дозволяють особистості адаптуватися й самореалізуватися в умовах сучасного суспільства, тобто успішно пройти соціалізацію. У дослідженні О.Максимової зазначено, що соціальна компетентність - це “відповідна інтеграція знань, умінь і ставлень, які планомірно, 
цілеспрямовано і систематично розвиваються під час виховання й навчання, що забезпечує оптимальну адаптацію до ш коли, а також виокремлено такі ii компоненти, як знання, уміння діяти відповідно до ситуації та ставлення до інших" [7].

На думку дослідників, для наукового аналізу проблеми формування соціальної компетентності дітей старшого дошкільного віку важливим є врахування вікових особливостей розвитку дитини в дошкільний період, серед яких такі:

"1) дитина-дошкільник як особистість перебуває на етапі становлення, дозрівання і розвитку; формування основ особистісної активності, самостійності, ініціативності, відповідальності та особистісного становлення;

2) самоцінність цього періоду визначається наявністю дитячої субкультури;

3) дошкільний вік (3-6 років) пов'язаний з домінуванням ігрової діяльності;

4) дитячі види діяльності мають специфічний характер і формують головні досягнення дитини у їі фізичному, психічному та соціальному розвитку, завжди відповідають інтересам і потребам дитини;

5) це сенситивний період для первинної соціалізації особистості;

6) період формування ціннісного ставлення до природи, культури, людей і самого себе, орієнтації на світ людей, осягнення змісту і форм людських стосунків;

7) висока емоційна насиченість усіх сфер життєдіяльності дитини, їі допитливість, безпосередність, оптимізм як важлива передумова для емоційнопрактичного пізнання довкілля і самої себе.

8) чутливість до соціально-психологічних механізмів навіювання, наслідування. На думку Кузьменко В.Д., вищезгадані механізми дають дитині можливість розвивати соціальну сферу, рефлексувати і відповідати соціальним очікуванням суспільства [6].

Висновки та перспективи подальших досліджень. Отже, соціальна компетентність у старшому дошкільному віці розглядається вченими як відповідна інтеграція знань, умінь і ставлень, які планомірно, цілеспрямовано та систематично розвиваються під час виховання та навчання і забезпечують оптимальну адаптацію до школи.

На думку дослідників зміст компонентів (аспектів) соціальної компетентності охоплює:

- знання як результат духовної та практичної діяльності людей, виражений у системі фактів, уявлень, правил, законів і теорій;

- уміння належно виконувати певні дії (розвивається за допомогою вправ) та створення можливостей виконання цих дій не тільки у звичних, а й у змінних умовах;

- ставлення, тобто стійке емоційне налаштування старшого дошкільника, яке проявляється в діянні та відображає значення явищ, що пов'язані з потребами та мотивами.

Результати досліджень доводять, що соціально компетентні діти значно легше, ніж їхні менш компетентні однолітки, адаптуються до вимог школи. Водночас спеціально організована робота може зробити ситуацію переходу менш стресовою для дитини. Найбільш пристосованим для цього є навчально-виховний комплекс: дошкільний навчальний заклад - початкова школа, який має можливості звичайного закладу та, разом з тим, найбільш зручні психолого-педагогічні умови для організації діяльності із соціальної адаптації дитини до нових реалій. Здійснений теоретичний аналіз наукових джерел 3 проблеми дослідження дав можливість фахівцям визначити соціальну компетентність в якості відповідної інтеграції знань, 
умінь і ставлень, які планомірно, цілеспрямовано та систематично розвиваються під час виховання та навчання, що забезпечує оптимальну адаптацію дитини до школи, а також виокремити такі критерії соціальної компетентності, як когнітивне знання про оточуючий світ, діяння в оточуючому просторі, емоційно-ціннісні прояви ставлення до інших, що розвиваються в дошкільному віці.

\section{Література}

1. Авраменко О. Соціалізація дошкільника крізь призму педагогічних поглядів маріїмонтессорі // Збірник наукових праць Уманського державного педагогічного університету. - Умань, 2014. Ч. 3. - С. 8-14.

2. Базовий компонент дошкільної освіти в Україні // Дошкільне виховання - 2012. - №7. - С.419.

3. Голованова Н.Ф. Педагогические основы социализации младшего школьника: Дисс. ... д-ра пед. наук. - С.-Пб., 1996. - 327 с.

4. Докторович М.О. Соціальна компетентність особистості: ознаки, функції та етапи формування// Електронний ресурс: http://ps.stateuniversity.ks.ua/file/issue_48/86.pdf

5. Дурманенко О. Розвиток соціальної компетентності дошкільників у процесі спілкування 3 дорослими // Молодь і ринок №7 (138), 2016 .- С. 54-59

6. Кузьменко В. Д. Соціальна компетентність дошкільнят: особливості, показники та шляхи розвитку / Кузьменко В. Д. // Дошкільне виховання. - 2001 - №9.- С. 15, 18-20.

7. Максимова О. О. Формування соціальної компетентності дитини дошкільного віку як запорука iï успішної адаптації до навчання в школі / О. О. Максимова // Педагогічна освіта : теорія і практика. Збірник наукових праць. - Вип. 20 (1-2016). - Ч. 2. - Кам'янець-Подільский : Кам'янецьПодільський національний університет імені Івана Огієнка, 2016. - С. 229-234.

8. Сухомлинський, В. О. Вибрані твори : в 5-ти т. / В. О. Сухомлинський. - К. : Рад. школа, 1976. - T. 2. $-670 \mathrm{c}$.

\section{References}

1. Avramenko O. Sotsializatsiia doshkilnyka kriz pryzmu pedahohichnykh pohliadiv mariimontessori // Zbirnyk naukovykh prats Umanskoho derzhavnoho pedahohichnoho universytetu. - Uman, 2014. Ch. 3. - S. 8-14.

2. Bazovyi komponent doshkilnoi osvity v Ukraini // Doshkilne vykhovannia. - 2012. - №7. - S.4-19.

3. Holovanova N.F. Pedahohycheskye osnovy sotsyalyzatsyy mladsheho shkolnyka: Dyss. ... d-ra ped. nauk. - S.-Pb., 1996. $-327 \mathrm{~s}$.

4. Doktorovych M.O. Sotsialna kompetentnist osobystosti: oznaky, funktsii ta etapy formuvannia// Elektronnyi resurs: http://ps.stateuniversity.ks.ua/file/issue_48/86.pdf

5. Durmanenko O. Rozvytok sotsialnoi kompetentnosti doshkilnykiv u protsesi spilkuvannia $z$ doroslymy // Molod i rynok №7 (138), 2016 .- S. 54-59

6. Kuzmenko V. D. Sotsialna kompetentnist doshkilniat: osoblyvosti, pokaznyky ta shliakhy rozvytku / Kuzmenko V. D. // Doshkilne vykhovannia. - 2001. - №9.- S. 15, 18-20.

7. Maksymova O. O. Formuvannia sotsialnoi kompetentnosti dytyny doshkilnoho viku yak zaporuka yii uspishnoi adaptatsii do navchannia v shkoli / O. O. Maksymova // Pedahohichna osvita : teoriia i praktyka. Zbirnyk naukovykh prats. - Vyp. 20 (1-2016). - Ch. 2. - Kamianets-Podilskyi KamianetsPodilskyi natsionalnyi universytet imeni Ivana Ohiienka, 2016. - S. 229-234.

8. Sukhomlynskyi, V. O. Vybrani tvory : v 5-ty t. / V. O. Sukhomlynskyi. - K. : Rad. shkola, 1976. - T. 2. $-670 \mathrm{~s}$. 